\title{
Research on the Service Innovation Model of Scenic Spots - A Case Study of Chime-Long Paradise
}

Guo Chunfan ${ }^{*}$, Chen Yixiao

Management School of Jinan University, Guangzhou 510632, China

DOI: $10.36347 /$ sjebm.2020.v07i01.003

| Received: 01.01.2019 | Accepted: 10.01.2020 | Published: 16.01.2020

*Corresponding author: Guo Chunfan

Abstract

Original Research Article

In the rapidly changing market environment, how could scenic spots innovate their services more effectively? In order to solve this problem, this paper constructs a theoretical framework of "internal and external environment $\rightarrow$ cultural tourism integration path $\rightarrow$ service innovation model" and takes Chime-Long Paradise as research object. The results indicate that: (1) Driven by internal and external environmental factors, the service innovation model of scenic spots presents the evolutionary track of "tangible product value-added model $\rightarrow$ market expansion model $\rightarrow$ value promotion model". (2) Integration paths of culture and tourism influent the evolution of the model of service innovation in scenic spots differently: resource integration and technology integration provide the essential foundation for the service innovation; market integration and function integration jointly promote the evolution of service innovation. However, market integration and function integration cannot be separated from resource integration and technology integration to work.

Keywords: Integration of Culture and Tourism; Service Innovation; Scenic Spots.

Copyright @ 2020: This is an open-access article distributed under the terms of the Creative Commons Attribution license which permits unrestricted use, distribution, and reproduction in any medium for non-commercial use (NonCommercial, or CC-BY-NC) provided the original author and source are credited.

\section{INTRODUCTION}

In recent years, the integration of culture and tourism industry has become the general trend. In 2018, the consumption demand of China's cultural tourism industry is 2,701.2 billion yuan, and the compound growth rate of demand scale of cultural tourism industry from 2013 to 2018 is $13.68 \%$ [2]. However, in the trend of integration of culture and tourism, there are still many problems in scenic spots, such as the absence of cultural connotation in service, lack of service product characteristics, outdated management patterns and so on. At the meeting of the directors of the Chinese National Department of Culture and Tourism in 2019, it was pointed out that the integration of China's culture and tourism industry is still in its infancy. We still need strive to promote the integration of culture and tourism industry, promote the cultural empowerment of scenic spots, and promote the upgrading of existing integrated development formats such as theme parks, cultural theme hotels and cultural heritage tourism [3].

However, in the existing literature, few researches concern about the service innovation model of scenic spots, especially its the evolutionary path. In an increasingly uncertain market environment, there is no service innovation model applicable to all scenarios [1]. Changes in internal and external environmental factors such as government policies, market demand and corporate strategy will affect the innovation of scenic spots [2]. The sustainable development of scenic spots can only be realized by overcoming path dependence and carrying out service innovation practice that is compatible with the environment.

In addition, few studies have explored service innovation model of scenic spots from the perspective of cultural and tourism industry integration. However, as an important part of tourism industry, the development of scenic spots is closely related to the integration of culture and tourism industry. Scenic spots, such as theme parks and red tourist destinations, are exactly the product of cultural and tourism industry integration. The tourism performance projects, tourism festivals and events in the scenic spot are also the results of the integration of culture and tourism [3]. Under the background of cultural and tourism industry integration, how should scenic spots explore appropriate service innovation model to adapt to environmental changes? Will different integration paths of culture and tourism affect the evolution of service innovation model of scenic spots? These problems have not been solved. 
LITERATURE REVIEW AND THEORETICAL BASIS

\section{Service Innovation Model}

In a narrow sense, service innovation refers to the application of new ideas and technologies in the service process to improve the existing services or create new services, including content innovation and transmission innovation [4-6]. Content innovation usually refers to a new service content or function, an increase or promotion of the original service function, a new service content realized by the split or reorganization of the original service function [6]. Transmission innovation refers to the innovation of interaction with customers in the process of service transmission [7]. In a broad sense, all innovation activities related to service belong to service innovation, which means that in addition to content innovation and transmission innovation, organizational innovation and marketing innovation also belong to service innovation [8]. This paper focuses on the narrow sense of service innovation.

Service innovation model refers to the basic framework system and thinking method that enterprises or organizations follow when carrying out new services [9]. Researchers classified and named innovation models according to different driving factors [10], different innovation content $[11,12]$, different innovation degree [13], etc. It should be noted that innovation model needs to be classified and named according to the different characteristics of service innovation in each stage of the research object.

In the turbulent and changing environment, service innovation model is not unchangeable. The complexity and uncertainty of the external environment is an important reason for the organization to continuously adjust its service innovation model [14]. The measurement of external environmental factors usually includes market demand, government policy, competition intensity etc [15]. In addition, internal factors will also have a vital impact on the service innovation model, such as strategic decision and management behavior. Strategic decision is the most fundamental and effective internal innovation driving factor [16]. Enterprises need to build corresponding innovation network based on enterprise innovation strategy according to different environmental requirements [17]. Besides, management behavior, which mainly refers to the business management activities of top management and marketing departments, is another key internal driving factor [16]. Enterprises can trigger innovation activities through strategic planning and corresponding management activities [18].

\section{The relationship between industrial integration and service innovation}

Industrial integration refers to the intersection, penetration and integration of different industries or different industries within the same industry. It is a kind of convergence and combination between separated markets and the elimination of barriers to entry of industrial boundaries [19]. Industrial integration is closely related to service innovation. Firstly, industrial integration can not only promote conceptual innovation, but also affect the original service functions and contents of enterprises. For example, the integration of sports industry and education industry enriches and improves the functions of stadiums and gymnasiums, which not only strengthens the original service functions of sports industry(such as sports competition and fitness), but also adds new service functions for sports industry (such as education and training) [20]. Industrial integration will also change the interaction between enterprises and customers, and promote service transmission innovation. For example, the integration of equipment manufacturing industry and high-tech service industry will increase the interaction opportunities with customers in the service process and make the service interaction more intelligent [21].

Industrial integration paths include resource integration, market integration, technology integration and function integration. Resource integration refers to the integration of related industries in the form of resources, which can expand the original resources continuously. Technology integration refers to the active introduction of relevant technologies from other industries to form a new type of business. Market integration refers to the integration of two or more industries which have common target markets. Function integration path refers to the integration of two or more industries with similar functions [22, 23]. Previous studies have shown that several factors will affect the choice of industrial integration path [24], such as the development of information technology, the change of market demand, the profit demand of enterprises and the optimization of policy environment and so on. In addition, different integration paths will bring different resources to enterprises and affect industrial innovation [23].

\section{Service Innovation of Scenic Spots}

Scenic spot is the product of the integration of culture and tourism industry [25]. According to the service classification method proposed by Lovelock [26], services of scenic spots are tangible services which focus on human body. According to the definition of service innovation in a narrow sense, this paper defines the model of service innovation in scenic spots as the content innovation and transmission innovation based on the original service. Content innovation of scenic spots refers to the brand-new or improved service content. Transmission innovation of scenic spots refers to the innovation of interaction methods between scenic spots and their customers.

Previous research on the model of service innovation in scenic spots mainly focused on the impact 
of the development of information technology on the enhancement of service experience value. Li Wei et al., pointed out that the rapid development and wide application of information technology laid a solid technical foundation for the service innovation of scenic spots [27]. Styliadis et al., paid attention to the application of GIS database and virtual reality technology in the innovation activities of ancient relics scenic spots [28]. Werthner et al., analyzed the specific application of mobile social software in the service innovation of tourist attractions [29]. Ford et al., took Disney as an example, from the perspective of customer experience improvement, divided service innovation into experience promotion innovation, experience promotion innovation, experience reshaping innovation and new experience innovation [30]. Liu Shaoai et al., pointed out that it is very important for scenic spots to build interactive platform and personalized experience environment for tourists [31].

\section{RESEARCH FRAMEWORK}

Previous studies have demonstrated that the change of internal and external environment is the premise of the evolution of service innovation model. However, there was no literature exploring the evolution of service innovation model of scenic spots under the influence of environmental factors. The research of industry integration have showed that industry integration is helpful to the realization of service innovation. In addition, researchers have pointed out that environmental factors can affect the organization's choice of industrial integration path. Besides, four kinds of integration paths would promote industrial innovation. But few literatures have explored the impact of different industrial integration paths on service innovation. There is no denying that the integration of culture and tourism industry is closely related to the development of scenic spots. For scenic spots, the integration of culture and tourism is an important way to obtain service innovation resources and carry out service innovation, but few literatures have explored the evolution of service innovation model of scenic spots from the perspective of cultural and tourism industry integration.

There are three purposes of service innovation of scenic spots. The first one is to increase the value of tangible products (such as hardware amusement facilities, intelligent interpretation system, etc.). Under the guidance of this goal, the service innovation of the scenic spot will be closely related to the hardware products. The second one is to increase the number of tourists. Under the guidance of this goal, scenic spots are required to have a strong ability to respond to market demand. What's more, service innovation would be no longer limited to the original scope of service, or limited to the existence of tangible products. Improving the interaction of service and customer participation would become the emphasis of service innovation. The third one is to enhance the experience value of customers. Under the guidance of this goal, scenic spots need to rethink their service function positioning and increase the cultural connotation of their services.

Therefore, this paper proposes the following research framework (Figure-1). Driven by internal and external environmental factors, scenic spots need to change their original services and explore suitable service innovation models. And the four kinds of integration paths of culture and tourism provide a variety of possibilities for the service innovation of scenic spots. In the development of scenic spots, the choices and applications of these four integration paths ultimately lead to the evolution of service innovation model of scenic spots.

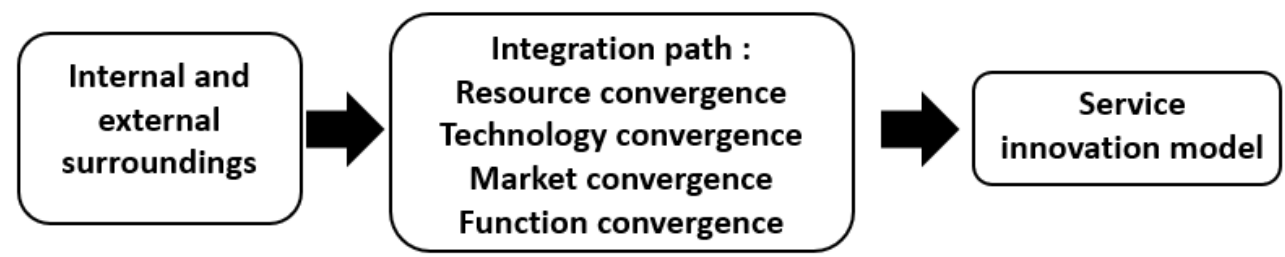

Fig-1: Schematic diagram of research framework

\section{RESEARCH METHOD}

This paper uses case study method to reveal the evolution path of service innovation model of scenic spots under the background of the integration of tourism industry and cultural industry. There are four reasons for choosing this method. Firstly, it can display and analyze the research problems vividly and carefully. Secondly, it can reveal the dynamic and integrity of process change. Thirdly, it is helpful to grasp the micro mechanism by choosing single case for exploratory research. Since the existing researches have rarely involved the research on the service innovation model of tourist attractions under the integration of culture and tourism industry, we require detailed case materials and data as support.

\section{The selection of case enterprises and its general situation}

This paper selects Chime-Long Paradise ( hereinafter referred to as "CLP") as the observation object. The case selection follows the following principles. (1) Principle of industry typicality.CLP is the product of the integration of culture and tourism industry, and its development process is also the 
exploration process of the service innovation model of scenic spots under the integration of culture and tourism industry. (2) Principle of data availability.CLP has been established for a long time, with rich retrospective data, which can track its long-term service innovation process. (3) Principle of adaptability. The environment faced by the case object is complex and changeable, and its service innovation is closely related to the integration of culture and tourism industry.

CLP is a super large theme park which integrates ride, stunt theater, tour performance, ecological leisure, characteristic catering, theme store and other services. Since its official opening on April 7, 2006, it has received more than 30 million tourists so far. It has set a record of receiving 100000 visitors a day in theme parks, and is known as "the model of a new generation of amusement parks in China"1.

\section{Case data source and collection method}

According to the research recommendations of Eisenhardt [32] and Yin [33], this study uses a variety of sources to collect data, including: semi-structured interviews, field investigations and second-hand data collection.

\section{Field Investigations and Semi-Structured Interview}

In November 2017, January 2018 and March 2018, the research team conducted three field investigations and two in-depth interviews in CLP. The interviewees were senior managers of CLP, and each interview lasted for 1 to 3 hours. In addition, the research team conducted several follow-up online interviews. After each interview, a team discussion would be conducted to verify the consistency of the materials and explore the inadequacies of the data, so as to make follow-up corrections and ensure the integrity and effectiveness of the case data.

\section{Second Hand Data Collection}

The research team collect second-hand information through official websites, consulting agencies, enterprise yearbooks and other channels. The multi-level and multi-source data collection method can be used to cross check the interview and control the backtracking bias, which can enhance the accuracy of the research results.

\section{Data Analysis Process}

In this paper, multi-level coding method is used for data analysis. In order to avoid homology bias, subjectivity and cognitive difference, the following methods are adopted. Two researchers discussed the results of data coding. When one of them put forward a point of view, the other members took the role of support or refuter to verify, supplement or criticize the point of view until they were consistent. In addition, if any contradiction is found, researchers would further confirm the original data, or visit relevant personnel for correction.

\section{Data Analysis Steps}

First, researchers classified data according to data sources (Table-1). Second, researchers extracted the keyword tag, made the first level coding and got 11 labels. Meanwhile, the key events and main stages of service innovation were identified. Third, based on the literature, researchers encoded stage by stage and extracted 6 subcategories from the first level coding. Finally, formed 3 fundamental categories according to the relevant literature results.

${ }^{1}$ The official website of Chime-Long Paradise. https://gz.chimelong.com/happy/about/index.shtml\#menu 
Table-1: Case data analysis

\begin{tabular}{|l|l|l|l|}
\hline Data Sources & Data Classification & Data Properties & Code \\
\hline \multirow{3}{*}{ First-hand data } & Data obtained from depth interviews & Real time data & F1 \\
\cline { 2 - 4 } & Data obtained from field observation & Real time data & F2 \\
\cline { 2 - 4 } & Data obtained from informal interview & Real time data & F3 \\
\hline \multirow{2}{*}{ Second-hand data } & Data obtained from enterprise website & Retrospective data & S1 \\
\cline { 2 - 4 } & Data obtained from news report, industry Report & Retrospective data & S2 \\
\hline
\end{tabular}

\section{CASE FINDING}

According to the coding results, this paper divides the development process of CLP into three stages: start-up, growth and upgrading. The evolution of service innovation model of CLP presents the evolution path of "tangible product value-added type $\rightarrow$ market expansion type $\rightarrow$ value promotion type" (Figure-2).

\section{Initial phase: tangible product value-added model (2006-2008)}

Around 2006, the domestic theme park market competition was not fierce, which gave CLP a good chance to develop. In terms of content innovation, CLP focused on the consolidation and promotion of amusement service functions. Cooperated with leading amusement equipment companies from Switzerland,
Holland and Germany, CLP purchased several firstclass amusement facilities (vertical roller coaster, super big pendulum, U-shaped skateboard, etc.). In addition, in order to solve the problems of homogeneous amusement projects and relieve the pressure of peak season, CLP added some exotic amusement projects such as North American logging show, Hollywood stunt show and so on. Through the integration of performance resources and hardware facilities, the core entertainment service function got consolidated and improved. In terms of transmission innovation, CLP launched fast passing services ("happy fast wrist strap", "Fast and easy wrist strap", etc.) for popular facilities, which improved the efficiency of transmission of amusement services. Table 2 shows the coding results and typical quotation examples of this phase.

Table-2: Coding examples of the initial phase

\begin{tabular}{|c|c|c|c|c|}
\hline $\begin{array}{l}\text { Fundamental } \\
\text { category }\end{array}$ & Subcategory & Origin & Typical quotation & Label \\
\hline \multirow[t]{4}{*}{$\begin{array}{l}\text { Internal and external } \\
\text { environmental factors }\end{array}$} & \multirow[t]{2}{*}{ External factors } & F1 & $\begin{array}{l}\text { Began to focus on stimulating } \\
\text { amusement facilities, } \\
\text { difficult to meet all needs }\end{array}$ & Market demand \\
\hline & & F3 & $\begin{array}{l}\text { At that time, the domestic theme park } \\
\text { market was depressed }\end{array}$ & $\begin{array}{l}\text { Competitive } \\
\text { intensity }\end{array}$ \\
\hline & \multirow[t]{2}{*}{ Internal factors } & F1 & $\begin{array}{l}\text { In } 2006 \text {, more than } 45000 \text { visitors came } \\
\text { to the park on May } 1,2006 \text {, and the } \\
\text { park was almost paralyzed }\end{array}$ & $\begin{array}{l}\text { Operation and } \\
\text { management }\end{array}$ \\
\hline & & F1 & Make the best product & $\begin{array}{l}\text { Strategic } \\
\text { decision }\end{array}$ \\
\hline \multirow[t]{2}{*}{$\begin{array}{l}\text { Integration of culture } \\
\text { and tourism industry }\end{array}$} & \multirow[t]{2}{*}{ Integration path } & F1 & $\begin{array}{l}\text { We will cooperate with whoever has } \\
\text { good technology }\end{array}$ & $\begin{array}{l}\text { Technology } \\
\text { convergence }\end{array}$ \\
\hline & & $\mathrm{S} 2$ & $\begin{array}{l}\text { Add new deductive resources and } \\
\text { entertainment elements }\end{array}$ & $\begin{array}{l}\text { Resource } \\
\text { convergence }\end{array}$ \\
\hline \multirow[t]{2}{*}{$\begin{array}{l}\text { Service innovation } \\
\text { model }\end{array}$} & \multirow[t]{2}{*}{$\begin{array}{l}\text { Market expanding } \\
\text { service innovation }\end{array}$} & S1 & $\begin{array}{l}\text { Improve the function of amusement } \\
\text { service by introducing hardware } \\
\text { equipment }\end{array}$ & $\begin{array}{l}\text { Content } \\
\text { innovation }\end{array}$ \\
\hline & & $\mathrm{F} 2$ & $\begin{array}{l}\text { Launch a series of fast track services } \\
\text { for popular facilities }\end{array}$ & $\begin{array}{l}\text { Transmission } \\
\text { innovation }\end{array}$ \\
\hline
\end{tabular}

\section{Growing phase: market expansion model (2009-} 2013)

After 2008, affected by the financial crisis, the demand of theme park market decreased. In 2009, with the addition of new parks by Hong Kong Disneyland and the opening of overseas Chinese town in Shenzhen, competition in the domestic theme park market intensified. In the same year, the Chinese government issued "opinions of the State Council on accelerating the development of tourism" and other policies, explicitly encouraging the development of large-scale theme parks.

In order to rapidly expand the market and further improve the function of recreation services, CLP actively sought the integration point of cultural market and tourism market. In addition to acting resources, festivals, films and other cultural resources were also incorporated into CLP's service system. In terms of content innovation, CLP paid more attention to the formation of its own cultural characteristics. For 
example, it integrated more traditional Chinese cultural elements into the park design, designed its own cartoon images, created its own Halloween activities. In terms of transmission innovation, it paid more attention to customers' participation, which meant increase interaction with customers in service. What's more, service innovation no longer only relies on the existence of tangible products. For example, during the Halloween Carnival, CLP provides free "ghost makeup" services for tourists. Table-3 shows the coding results and typical quotation examples of this phase.

Table-3: Coding examples of the growing phase

\begin{tabular}{|c|c|c|c|c|}
\hline $\begin{array}{l}\text { Fundamental } \\
\text { category }\end{array}$ & Subcategory & Origin & Typical quotation & Label \\
\hline \multirow[t]{5}{*}{$\begin{array}{l}\text { Internal and external } \\
\text { environmental factors }\end{array}$} & \multirow[t]{3}{*}{ External factors } & F1 & $\begin{array}{l}\text { After the financial crisis, the number of tourists } \\
\text { was greatly affected }\end{array}$ & Market demand \\
\hline & & F3 & $\begin{array}{l}\text { Overseas Chinese town opened in } 2009 \text { and the } \\
\text { market competition became stronger }\end{array}$ & $\begin{array}{l}\text { Competitive } \\
\text { intensity }\end{array}$ \\
\hline & & F1 & $\begin{array}{l}\text { Not only national policies encourage theme parks, } \\
\text { but the Guangzhou government has also been } \\
\text { supporting the development of CLP }\end{array}$ & $\begin{array}{l}\text { Government } \\
\text { policy }\end{array}$ \\
\hline & \multirow[t]{2}{*}{ Internal factors } & S2 & $\begin{array}{l}\text { In this stage, the investment in marketing has } \\
\text { increased }\end{array}$ & $\begin{array}{l}\text { Operation and } \\
\text { management }\end{array}$ \\
\hline & & $\mathrm{F} 1$ & Pay more attention to the spread of "happy culture" & Strategic decision \\
\hline \multirow[t]{3}{*}{$\begin{array}{l}\text { Integration of culture } \\
\text { and tourism industry }\end{array}$} & \multirow[t]{3}{*}{ Integration path } & F1 & Technology upgrades every year & $\begin{array}{l}\text { Technology } \\
\text { convergence }\end{array}$ \\
\hline & & S2 & $\begin{array}{l}\text { Pay more attention to the integration of film and } \\
\text { television resources and festival resources }\end{array}$ & $\begin{array}{l}\text { Resource } \\
\text { convergence }\end{array}$ \\
\hline & & S1 & $\begin{array}{l}\text { Continue to introduce high-quality film and } \\
\text { television works every year, cooperate with variety } \\
\text { shows, and expand the original market }\end{array}$ & $\begin{array}{l}\text { Market } \\
\text { convergence }\end{array}$ \\
\hline \multirow[t]{2}{*}{$\begin{array}{l}\text { Service innovation } \\
\text { model }\end{array}$} & \multirow[t]{2}{*}{$\begin{array}{l}\text { Market expanding } \\
\text { service innovation }\end{array}$} & F1 & Add CLP's features to Halloween activities & $\begin{array}{l}\text { Content } \\
\text { innovation }\end{array}$ \\
\hline & & F1 & $\begin{array}{l}\text { The purpose of free makeup is to let more tourists } \\
\text { participate in it }\end{array}$ & $\begin{array}{l}\text { Transmission } \\
\text { innovation }\end{array}$ \\
\hline
\end{tabular}

Upgrading phase: value promotion model (2014 to now)

After more than ten years of accumulation, CLP had made some achievements. But most of its amusement projects were imitations of foreign amusement parks, lacking their own cultural characteristics, which made it hard to meet rapidly changing market demand and maintain its long-term cultural vitality.

Table-4: Coding examples of the upgrading phase

\begin{tabular}{|c|c|c|c|c|}
\hline Fundamental category & Subcategory & Origin & Typical quotation & Label \\
\hline \multirow[t]{5}{*}{$\begin{array}{l}\text { Internal and external } \\
\text { environmental factors }\end{array}$} & \multirow[t]{3}{*}{ External factors } & F1 & $\begin{array}{l}\text { The needs of tourists are changing with each } \\
\text { passing day }\end{array}$ & Market demand \\
\hline & & F3 & $\begin{array}{l}\text { Not only theme parks, but also other types of } \\
\text { scenic spots are powerful competitors }\end{array}$ & $\begin{array}{l}\text { Competitive } \\
\text { intensity }\end{array}$ \\
\hline & & S2 & $\begin{array}{l}\text { Scenic spots should increase cultural } \\
\text { connotation and highlight local characteristics }\end{array}$ & $\begin{array}{l}\text { Government } \\
\text { policy }\end{array}$ \\
\hline & \multirow[t]{2}{*}{ Internal factors } & F1 & $\begin{array}{l}\text { Start to integrate with Chinese traditional } \\
\text { culture and break through the bottleneck }\end{array}$ & $\begin{array}{l}\text { Operation and } \\
\text { management }\end{array}$ \\
\hline & & F1 & $\begin{array}{l}\text { Committed to becoming a "cultural card" of } \\
\text { Guangzhou }\end{array}$ & Strategic decision \\
\hline \multirow[t]{4}{*}{$\begin{array}{l}\text { Integration of culture } \\
\text { and tourism industry }\end{array}$} & \multirow[t]{4}{*}{ Integration path } & F2 & Many new technologies are applied in the park & $\begin{array}{l}\text { Technology } \\
\text { convergence }\end{array}$ \\
\hline & & F1 & $\begin{array}{l}\text { Pay more attention to the integration of } \\
\text { traditional cultural resources }\end{array}$ & $\begin{array}{l}\text { Resource } \\
\text { convergence }\end{array}$ \\
\hline & & $\mathrm{S} 2$ & $\begin{array}{l}\text { Cooperate with music festivals and game } \\
\text { companies to win young market }\end{array}$ & $\begin{array}{l}\text { Market } \\
\text { convergence }\end{array}$ \\
\hline & & F1 & $\begin{array}{l}\text { The theme park just has the communication } \\
\text { platform needed by the festival }\end{array}$ & $\begin{array}{l}\text { Function } \\
\text { convergence }\end{array}$ \\
\hline \multirow[t]{2}{*}{$\begin{array}{l}\text { Service innovation } \\
\text { model }\end{array}$} & \multirow[t]{2}{*}{$\begin{array}{l}\text { Market expanding } \\
\text { service innovation }\end{array}$} & $\mathrm{S} 2$ & $\begin{array}{l}\text { "Happy town" integrates different types of } \\
\text { service facilities to meet the needs of various } \\
\text { market segments }\end{array}$ & $\begin{array}{l}\text { Content } \\
\text { innovation }\end{array}$ \\
\hline & & $\mathrm{S} 2$ & $\begin{array}{l}\text { Cooperate with gaming services company to } \\
\text { obtain popular game elements }\end{array}$ & $\begin{array}{l}\text { Transmission } \\
\text { innovation }\end{array}$ \\
\hline
\end{tabular}


In order to break through this bottleneck and improve the cultural experience value of services, CLP upgraded and reorganized the original service functions. On the one hand, CLP actively created amusement projects with Chinese traditional culture characteristics. Such as Chinese New Year celebrations, lantern parades, dragon-lion dances and so on. On the other hand, CLP added young pop culture elements to its festival activities. For example, in 2018, CLP and "strawberry" Music Festival jointly held a cross-year carnival. In the same year, CLP cooperated with the game "Arena of Valor" to make several kinds of virtual game scenes into reality. Besides, CLP designed a VR roller coaster with the theme of "Arena of Valor". Table-4 shows the coding results and typical quotation examples of this phase.

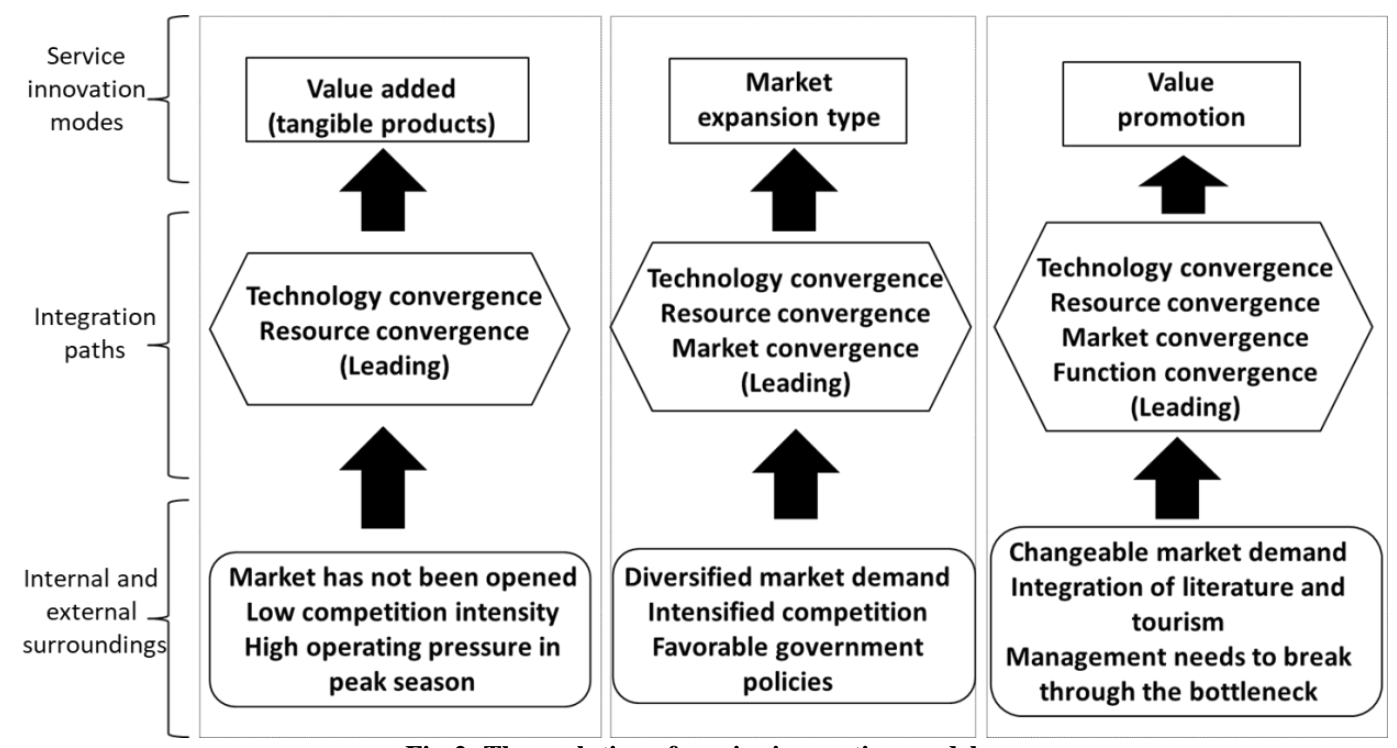

Fig-2: The evolution of service innovation model

\section{DISCUSSION}

According to the above research findings, there are three service innovation models in the development process of CLP: tangible product value-added model, market expansion model and value promotion model. And the realization of each kind of service innovation model is inseparable from the integration path of culture and tourism.

\section{Three Service Innovation Models and Their Comparison}

The common point of the three types of service innovation models is that they are mainly based on content innovation, supplemented by transmission innovation. Their differences are as follows. The first one is the difference in content innovation. Tangible product value-added model and market expansion model mainly focus on the amusement content, but the value promotion model also emphasizes the function of cultural experience and cultural transmission.

The second one is the difference in transmission innovation. Under the tangible product value-added model, transmission innovation relies on tangible products strongly. For example, in the early phase of CLP, transmission innovation was mainly realized through the improvement of hardware amusement facilities. However, under the other two models, transmission innovation can be separated from the existence of tangible products.
The third one is the difference in applicable situation. Tangible product value-added model is suitable for scenic spots that just start trying to upgrade their original service by means of cultural tourism integration. Market expansion model is suitable for the scenic spots which already have got some achievements and want to improve their service innovation results. Value promotion model is suitable for scenic spots that have accumulated rich service innovation achievements and want to break through their own cultural output bottleneck. In addition to the above, the degree of innovation, the difficulty of realization and the depth of cultural experience value of the three models increase in turn.

\section{Integration paths of culture and tourism and their} roles

Resource integration, technology integration, market integration and function integration play different roles in the evolution of service innovation model. Resource integration lays a necessary foundation for service innovation of scenic spots, while technology integration plays an important auxiliary role. Ding Yulian et al., also pointed out that the integration of technology and resources is the main path for the integration and development of culture and tourism in theme parks [25]. This is consistent with the findings of this study. In addition, this study also shows that market integration and function integration are the key ways to promote the evolution of service innovation model. However, without the integration of resources 
and technology, the integration of market and function will be difficult to make sense.

These four paths complement each other, play different leading roles in different stages. The findings also echo the views of Ma Xuefeng: In the practice of the development of new tourism formats, various integration paths are not isolated from each other, but interact with each other [23].

\section{THEORETICAL CONTRIBUTION PRACTICAL ENLIGHTENMENT Theoretical Contribution}

The theoretical contributions of this study are as follows. First, this paper sums up and compares three kinds of service innovation models of scenic spots. Second, this paper finds that different integration paths of culture and tourism have different effects on service innovation of scenic spots, and different integration paths of culture and tourism are not isolated from each other. Third, the analysis framework of "internal and external environment $\rightarrow$ cultural tourism integration path $\rightarrow$ service innovation model" is constructed. Under the background of the integration of culture and tourism, this paper explores the evolution track of the service innovation model of the scenic spot in order to realize the deep-seated cultural empowerment.

\section{Practical enlightenment}

This paper provides the following two practical implications for the service innovation of tourist attractions. First, the scenic spot should choose the suitable service innovation model according to its own development level. Hjalager et al., believed that, unlike traditional manufacturing innovation, imitators and followers of tourism innovation have more advantages than innovators [34]. However, this study shows that for scenic spots, in the initial stage, the imitation and learning of industry leaders can help consolidate the core service functions of scenic spots. But in order to maintain the long-term cultural output capacity, scenic spots need to create services which can reflect their cultural characteristics. For scenic spots with limited cultural output, two measures can be taken to realize deep cultural empowerment and service innovation. One is trying to deeply integrate with local culture. The other one is keeping sensitive to popular culture.

\section{REFERENCES}

1. $\mathrm{Xu} \mathrm{H}$, Zhang $\mathrm{HJ}$, Wang L. The construction mechanism of service innovation capability of manufacturing enterprises from the perspective of value driven -- a case study based on Emerson Network Energy (China) [J]. Management case study and review, 2014; 7(4):269-282.

2. Yao J. taking tourists as the center and technology as the starting point -- Discussion on the development of Chinese tourist attractions in the new era $[\mathrm{J}]$. Journal of tourism, 2018; 33(1):5-7.
3. Liang F, Guo BN. Research on the internal mechanism and path of the integration development of culture, tourism and business [J]. Technology economy and management research, 2016; (8): 114-118.

4. Barras R. Towards a Theory of Innovation in Services [J]. Research Policy, 1986, 15(4):161173.

5. Jian ZQ. Research on the influence of network and relationship mosaic on service innovation performance [M]. Science Press, 2014.

6. Wei Jiang, Wang Lin, $\mathrm{Hu} \mathrm{SR}$, Tao Yan. Classification of knowledge intensive service innovation [J]. Scientific research, 2008; 26(S1): 195-241.

7. Bilderbeek R, Hertog D, Marklund G. Service innovation: knowledge intensive business service as co-producers of innovation; 1998.

8. Miles I. Innovation in services [A]. Dodgson M, Roth-well R (Eds.), Handbook of Industrial Innovations [C]: US: Edward Elgar, 1994; 243 256.

9. Wang JZ, Wu GH. An analysis of the innovation model of Chinese tourism enterprises based on the four-dimensional model of service innovation -Taking Yunnan tourism as an example [J]. Business research, 2007; (8):1-6.

10. Rothwell R. Towards the Fifth-generation Innovation Process [J].International Marketing Review, 1994; 11(1):7-31.

11. Hollenstein H. Innovation Models in the Swiss Service Sector: a Cluster Analysis Based on Firmlevel Data [J]. Research Policy, 2003; 32(5):845863.

12. Sundbo J, Gallouj F. Innovation as a Loosely Coupled System in Service[R]. In: SI4S Topical Paper, 1998: 56-73.

13. Gallouj F, Weinstein O. Innovation in Services [J].Research Policy, 1997; 26(3):537-556.

14. Liu Yan, Feng LM, Huang Yujie. Research on the strategy of service outsourcing enterprises based on the evolution of innovation capability [J]. Science and technology progress and countermeasures, 2011; 28(17): 90-95.

15. $\mathrm{Xu} \mathrm{H}$, Zhang HJ. Research on construction mechanism and evolution path of service innovation capability of manufacturing enterprises [J]. Science research, 2016; 34(2): 298-311.

16. Hu Song, Lin Lei, Wu GS. Driving forces and models of service innovation [J]. Research and development management, 2006; (1):33-39.

17. Zheng YL, Pan ST. Multi level innovation network of focus enterprises and its dynamic evolution -- Taking Haining Leather City as an example [J]. Management world, 2013; (9):182183.

18. Zhao YW, Chen JH, Wang MY, Zhang YQ, Feng QH. Summary of service innovation in manufacturing enterprises: motivation, process and performance $[\mathrm{J}]$. China Science and 
Technology Forum, 2013;(2):78-81.

19. Lind J. Ubiquitous Convergence: Market Redefinitions Generated by Technological Change and the Industry Life Cycle [M]. New York: Troditional, Complementary and Altermative, 2014:472.

20. Li Yanyan, Lan Zili, Chen Xiyao. Characteristics, types and Realization Mechanism of sports industry integration in China $[\mathrm{J}]$. Journal of Capital Institute of physical education, 2015; 27(6):488-492.

21. Fu WZ, Jin M, Liu FF. Research on the integration development and effect evaluation of China's hightech service industry and equipment manufacturing industry under the background of industry 4.0 - based on the AHP information entropy coupling evaluation model $[\mathrm{J}]$. Industrial technology economy, 2017;36(12):90-98.

22. Zhang LY. Basis and premise of tourism industry integration [J]. Tourism journal, 2011, 26(4):6-7.

23. Ma XF, Zhang SB, Long MX. Path analysis of tourism industry integration $[\mathrm{J}]$. Economic geography, 2010;30(4):678-681.

24. Gao LJ, Xia JC. Dynamic mechanism, path and policy choice of China's tourism industry integration $[\mathrm{J}]$. Journal of Capital University of economics and trade, 2012, (2).

25. Ding YL, Zhao Yuan. Analysis on the motivation, path and main body of the integration of tourism industry -- Taking the integration of Shenzhen Huaqiang group to develop tourism theme park as an example $[\mathrm{J}]$. Human geography, 2013;28(4):126-131.
26. Lovelock $\mathrm{CH}$. Classifying Services to Gain Strategic Marketing Insights $[\mathrm{J}]$. Journal of Marketing, 1983, 47(3):9-20.

27. LI W, MU H. Tourist service innovation based on progress of information technology. Science and Technology Management Research. 2012;32(13):200-203.

28. Styliadis AD, Akbaylar II, Papadopoulou DA, Hasanagas ND, Roussa SA, Sexidis LA. Metadata-based heritage sites modeling with elearning functionality. Journal of Cultural Heritage. 2009 Apr 1;10(2):296-312.

29. Werthner H, Koo C, Gretzel U, Lamsfus C. Special issue on Smart Tourism Systems. Computers in Human Behavior. 2015 Sep $1 ; 50(\mathrm{C}): 556-7$.

30. Ford RC, Edvardsson B, Dickson D, Enquist B. Managing the innovation co-creation challenge. Organizational Dynamics. 2012;4(41):281-90.

31. Liu SA, Lu Changbao. Value co creation: the transformation and innovation path of tourist management concept in scenic spots $[\mathrm{J}]$. Human geography, 2016;31 (4):135-142.

32. Eisenhardt KM. Building theories from case study research [J]. Academy of Management Review, 1989;14(4):532-550.

33. Yin RK. Applications of Case Study Research (Applied Social Research Methods) [M]. Series, 4th ed. Thousand Oaks: Sage Publications, 2003.

34. Hjalager AM. Repairing innovation defectiveness in tourism $[\mathrm{J}]$. Tourism Management, 2002;23(5):465-474. 